The subject has been considered at length and with much thoroughness by Dr. Richard Andree, in a late number of Globus (Bd. 64, No. 22). He analyzes the names of the constellation in many languages, and explains its relation in primitive peoples to their calendars and agricultural procedures. He shows that among the most diverse races and in all parts of the globe, these stars have been chosen either to indicate the beginning of years or cycles, or to regulate festivals and recurrent ceremonies.

One who has also given fruitful attention to this question is Mr. R. G. Haliburton, whose results, many of them not yet published, are spoken of by Dr. J. C. Hamilton in the last (fifth) Report of the Canadian Institute of Toronto. He brings together a mass of curious information concerning primitive beliefs about these stars.

The question has special interest in American archæology. At the Anthropological Congress in Chicago last summer, Mrs. Zelia Nuttall read a paper in which she referred to the well-known fact that by these stars the Aztecs regulated their cycle of 52 years. If they had commenced their computation when at that season the Pleiades culminated at midnight, it would be about 4000 years ago,-a deduction which gives rise to interesting speculations.

\section{WHAT IS ARCHÆAN?}

BY ALFRED C. LANE, HOUGHTON, L. S., MiChIGAN.

When in the issue of the Nation for March r, I894, p. I63, I saw my friend Professor Tarr criticised for calling the Huronian Archæan, and saw the reviewer go on to state that the rocks in which magnetic iron ores mostly occur are not undoubted Archæan, I said, "This is too much."

The history of the words Azoic and Archæan shows the irony of fate in scientific usage so well as to be worthy the attention of the readers of Science.

The term Azoic was originally applied to all the preSilurian strata, at first including the intrusives. ${ }^{1}$ Later Foster and Whitney excluded them and applied the term to the metamorphic group or formation, ${ }^{2}$-composed of "Gneiss, Mica and Hornblende Slate, Chlorite, Talcose and Argillaceous Slate, and Beds of Quartz and Saccharoidal Marble,"-supposed to be the first detrital rocks, modified by heat. They expressly mention the association of magnetic iron ores with them ${ }^{3}$ and give Logan's division into two groups, which they say they failed to recognize on the south shore of Lake Superior. ${ }^{4}$ The Azoic rocks included all rocks below the Potsdam, ${ }^{5}$ existing as a geologic system in the Lake Superior region.

Dana objected to the application of the term Azoic, ${ }^{6}$ as a misnomer, since there are direct and indirect traces of life in the rocks to which it was applied, and proposed the term Archæan instead. In his use of the term, Archæan is a name applied to one of the four or five primary divisions of geologic time, co-ordinate with the term Palæozoic. In this he has been. followed by Geikie and Leconte. From the text-books of these three men, probably ninety-nine per cent of living American geologists have been taught. Moreover, Dana retained the

IVan Hise, Archæan and Algonkian, Bulletin No. 86, United States Geological Survey, r892, p. 470; but compare Foster and Whitney, p. 3 .

IIbid, p. 8 .

${ }^{4}$ Ibid., p. p. 8 ; ; compare Van Hise, loc. cit., p. 490.

SIbid., p. II.

"Van Hise, loc. cit., pp. 394, 473.

Manual of Geology, 1880, p. ${ }^{4}$.

BSummarized in Van Hise, loc. cit., p. ${ }^{6} 69$ term Azoic, ${ }^{7}$ applying it to the earlier part of the Archæan time, and to the latter part applying the term Eozoic in his manual of geology, Archæozoic in a paper published in $1892 .{ }^{8}$

The arrangement in Dana's text-book seemed an admirable one, was widely adopted, and all seemed serene, when.trouble arose. The first symptom of it appeared in a circular letter of the Director of the United States Geological Survey, wherein he suggested the division of Geologic time into ten periods, to which provisional names were given. ${ }^{\circ}$ The name Archæan was applied to a period below the Cambrian, co-ordinate with it, and separated from it by another period.

No comment nor notice was made on this degradation of the rank of the word, and of course in a provisional scheme it was not necessary. But when in pursuance of this letter the name Archæan was formally applied to a time division earlier than the time of deposition of the clastic rocks older than the Cambrian, and co-ordinate with Cambrian, ${ }^{10}$ the mischief was done.

The term Archoan, introduced to replace Azoic as a misnomer, has been so changed in application by the United States Geological Survey as to include only rocks which cannot but be Azoic.

There certainly could have been no life before the beginning of sedimentation.

The only reason for this change, that I know of, is given by Van Hise in the following words : ${ }^{11}$

"As here used the term Archæan is restricted to this fundamental complex. It is no longer possible to regard as a unit or treat together all pre-Cambrian rocks. The rocks included in the fundamental complex are everywhere called Azoic or Archæan. The crystallines and semi-crystallines above this complex, often called Archæan, must be distributed from the Devonian or later to the pre-Cambrian. It is clear that if Archæan is to remain a serviceable term it must be restricted to some unit. Such a unit is the fundamental complex, and to it this term is most appropriate."

Comment is hardly needful, in view of the fact that for some four hundred and seventy eight pages Professor Van Hise has been treating all the pre-Cambrian rocks together, and that, as he avers, "it is impossible to make a wholly satisfactory theoretical definition of the Archæan" (as he uses it).

I should perhaps add that while I still think that the Archæan will "remain a serviceable term," if retained in the sense in which it was proposed, and is used by all the leading text-books, not only in America, but also in England (Geikie), and Germany (Credner and Neumayr) and is employed by the Neues Jahrbuch für Mineralogie, Geologie, etc. (as one of four or five divisions of geologic time co-ordinate wlth Palæozoic), I do not here question the appropriateness of its division, nor attempt to combat the arguments so ably urged by Van Hise ${ }^{12}$ for the crustal or sub-crustal character of the fundamental complex. I merely cannot see why the time-division given by Dana is not satisfactory, and why the time previous to the formation of clastics should not be called Azoic. Then for a parallel formation term, according to the principles of that dual nomenclature, rightly proposed by $H$. S. Williams, Van Hise's term Basement Complex seems to me very appropriate. Possibly Basal, as somewhat shorter, and in adjectival form more correspondent with other terms, might be better. The age of the Basal, so far as formed by subcrustal consolidation, might not be altogether Azoic, but it would all belong to one formation.

${ }^{9}$ Tenth Annual Report of the Director, United States Geological Survey, r89o, p. 59. ${ }^{10}$ Ibid., p. 66.

11 Van Hise, loc. cit, p. $47^{8}$.
12 Van Hise, American Journal of Geology, vol, i., p. xr3. 